\title{
China joins world-class synchrotron club
}

\section{Nation's costliest science facility is unveiled.}

\section{SHANGHAI}

The Shanghai Synchrotron Radiation Facility (SSRF) officially opened its doors last week to a queue of scientists waiting hungrily for beamline time. The 1.2-billion renminbi (US\$176-million) light source is China's biggest investment in a single science facility to date, says Zhao Zhentang, an accelerator physicist and the facility's deputy director.

The synchrotron radiation is generated as magnets bend an electron beam around the main ring's 432-metre circumference. "It's like mud coming off a spinning tyre," says Herman Winick, assistant director emeritus of the Stanford Synchrotron Radiation Laboratory in California, and chair of the committee of 30 international and 4 Chinese scientists who last week gave the go-ahead to approve the facility's first seven beamlines.

The light ranges from high-energy, hard $\mathrm{X}$-rays (10 kiloelectronvolts and above) through to infrared frequencies. It is channelled into a number of beamlines jutting out from the main ring, where it can be used for spectroscopy and diffraction experiments in fields including condensed-matter physics, structural biology and medical imaging.

In 2001, the Chinese government rejected plans for a new synchrotron light source, unconvinced that it would have enough users. Zhao and his colleagues resubmitted the proposal in June 2004 with the endorsement of scientists from more than 100 universities and some 20 institutes of the Chinese Academy of Sciences.

Since then, the project has progressed apace. Construction began on 25 December 2004, and the first synchrotron light was seen within three years, on 24 December 2007. "It's got to be a world record," says Winick. The facility is expected to have 30 working beamlines within 5 years, with the potential for up to 60 lines.

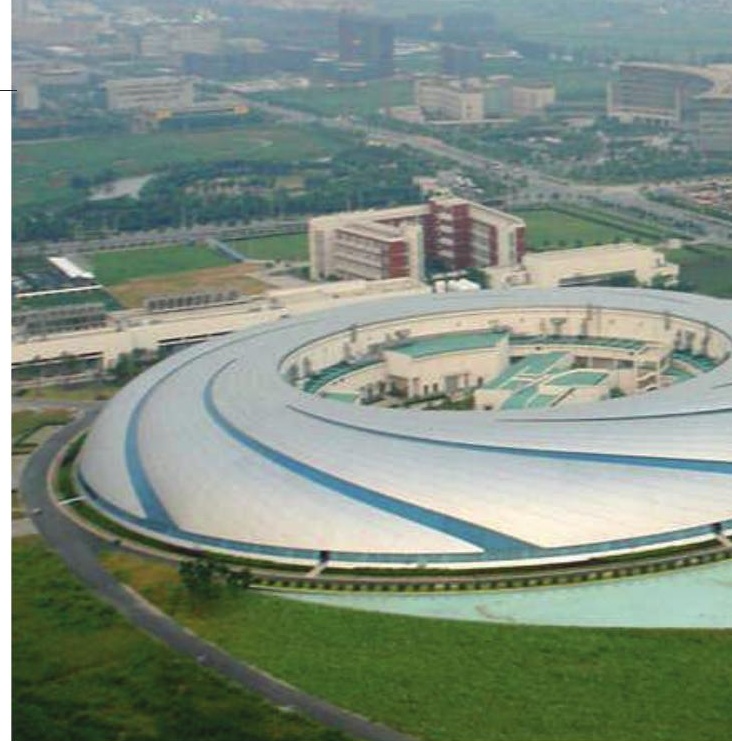

The Shanghai synchrotron is drawing Chinese scientists back from abroad.

More than 60 synchrotron radiation facilities operate worldwide, with a fresh crop of cutting-edge light sources in the works (see 'Leading lights'), giving fairly routine access to scientists in most countries that invest in such research.

Before the SSRF started up, China had two light sources, in Beijing and Hefei. But these are relatively small and cannot generate hard

\section{Leading lights}

China is not the only country brightening up its $\mathrm{X}$-ray sources. Two other new light-source facilities, the Linac Coherent Light Source (LCLS) in Stanford, California, and the PositronElectron Tandem Ring Accelerator (PETRA) III, in Hamburg, Germany, have opened in the past month. And more than a dozen are under way elsewhere (see map).

This 'fourth generation' of new facilities improves on older synchrotrons by making photon beams that are many orders of magnitude brighter, and delivering much shorter-duration light pulses.

Some of the new-generation facilities, called ultra storage rings, build on existing synchrotron technology. But others use approaches based on linear accelerators: free electron lasers (FEL) and energy recovery linacs (ERL). With bright, precisely timed pulses of light, they will allow scientists to create 'movies'

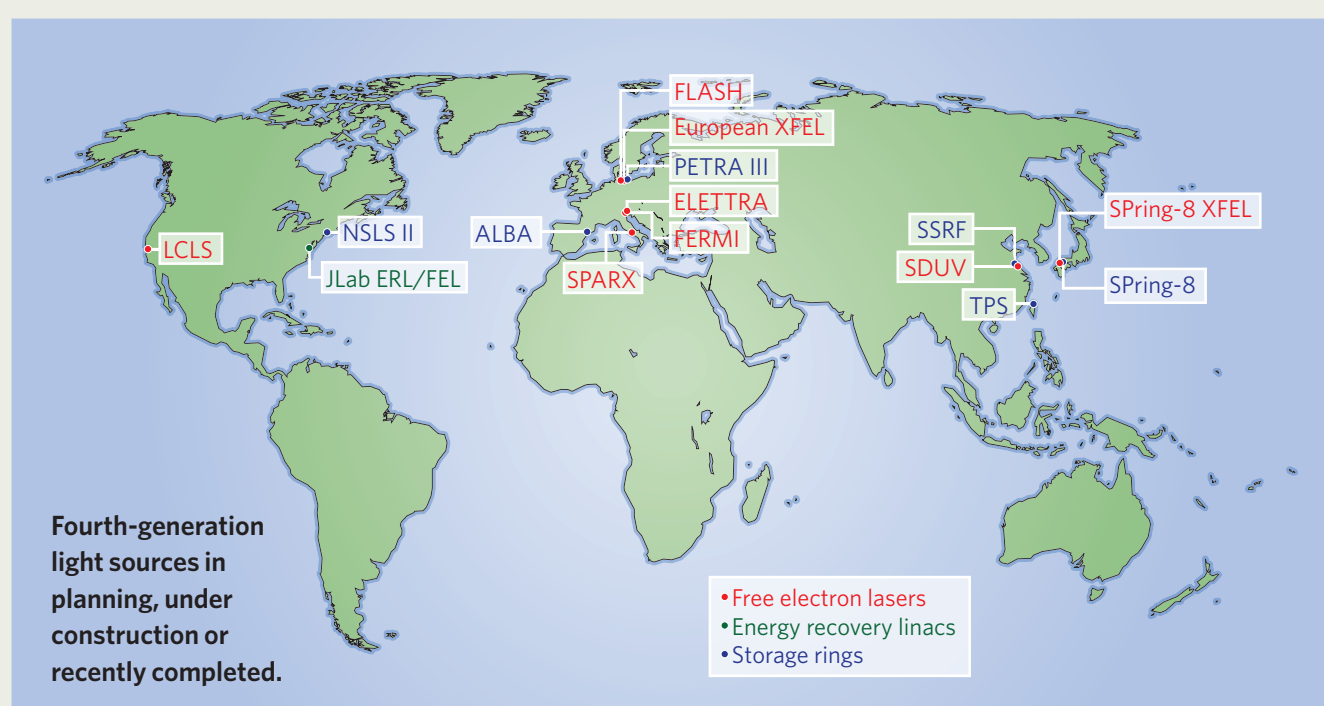

of atomic processes. They could reveal, for example, the step-bystep process of photosynthesis in a leaf, or the precise shape of a catalyst at the moment it becomes most chemically active.

Previous-generation light sources were something of a status symbol for countries wanting to join the high-tech club, says Franz Himpsel, a physicist at the University of Wisconsin, Madison. But now countries are realizing that the research can translate into products that have an economic impact, says Steve Dierker, project director for the National Synchrotron
Light Source-II (NSLS-II) at Brookhaven National Laboratory in New York, which is due for completion in 2015. "Countries are investing in the basic scientific infrastructure to enable them to have a competitive edge in the marketplace," he says. Eric Hand 


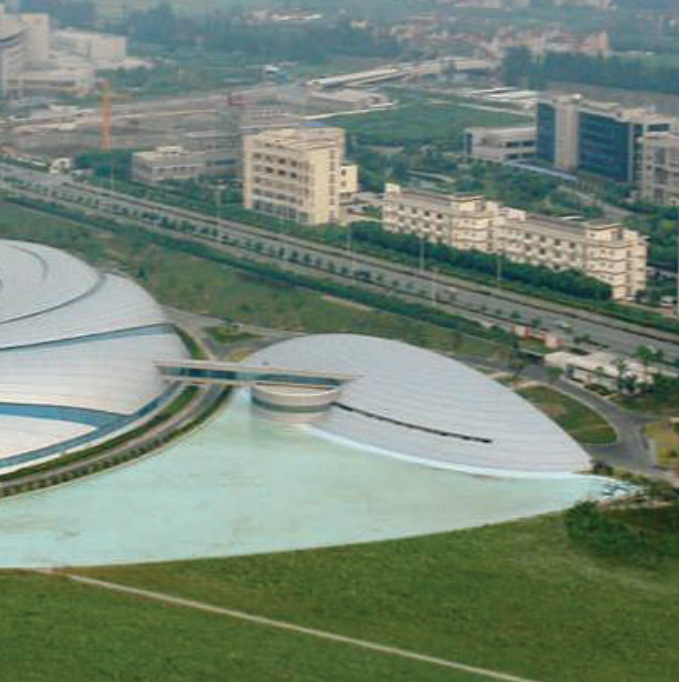

X-rays. For many Chinese scientists, who have lacked either the funding or the visas to use facilities abroad, the SSRF is a chance to see what cutting-edge synchrotrons can do.

Zhao hopes that the investment in worldclass facilities such as the SSRF will give Chinese scientists more reason to keep their research programmes in China, or to return from abroad. Indeed, Guo-Yuan Yang, a neurosurgeon who studied the mechanisms of cerebrovascular diseases for 20 years in the United States, says that he has returned to China in part because of the SSRF. Now based at Shanghai Jiao Tong University, he says the beams will allow him to examine, for example, real-time changes in small blood vessels seen in arteriovenous malformation - a circulatory disorder. "In the past we had to sacrifice animals, but here we can follow them day by day," he says.

At another SSRF beamline dedicated to $\mathrm{X}$-ray absorption fine structure (XAFS), which is particularly suited to analysing the atomic structure of liquids, a group led by Guozhong Wu of the Shanghai Institute of Applied Physics is looking at the iron ion content in an ionic liquid to investigate its catalytic properties. The institute's Yuying Huang, who is in charge of the beamline, says 60 research groups from China have already requested time. "We are asking the government to build another [XAFS] line," he says.

Lili Chen of the Shanghai Institute of Materia Medica, who is using a beamline to look at the structures of complex proteins related to diabetes and other diseases, says there are already applications to use 7,000 hours of time on that beamline in 2010 - almost twice as much as has been budgeted for.

With demand that high, says Winick, "it's going to be a zoo here in a year".

David Cyranoski

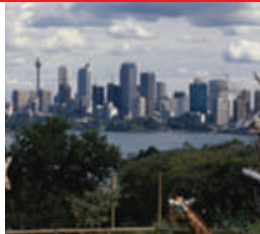

FLU MONITORING

Zoos help track the spread of pandemics.

www.nature.com/news

\section{Even big societies feel the pinch}

The American Chemical Society (ACS), the world's biggest scientific society, is feeling the effects of the global economic downturn.

On 28 April, six months after tightening its belt a first notch, the society laid off 56 people, $3 \%$ of its employees. New employment will be frozen indefinitely, and the society has capped its contributions to medical insurance for retired employees and cut back on other expenses such as travel.

The ACS, based in Washington DC, blames its financial problems on the falling values of its investments, as well as falling revenue from its publications, which include the Journal of the American Chemical

Society and Chemical \& Engineering News, as subscribers move from print to online-only deals. Its reserves were US\$60 million at the end of 2008, compared with $\$ 212$ million the year before.

\section{"The whole publishing enterprise has entered a} momentous time."

were laid off. The publications division generates more revenue than any other division of the society apart from the Chemical Abstracts Service, a fee-based database of chemical information and suite of tools to search it.

According to notes taken by a laid-off employee at a meeting of the publications division on 30 January, the ACS earns about $\$ 500$ million annually in revenues, with $29 \%$ from the publications division. In 2008, revenue growth in the division was just $2.5 \%$, down from $7-10 \%$ a year.

Ruskin says that the layoffs were strategically chosen. "The whole publishing enterprise has entered probably one of the more momentous times in its history: we are now moving from print to electronic," he says. "Part of what we are doing with the reduction is responding to that evolution."

Even vocal critics of the society's opposition to open-

The society has also posted a \$36.5-million bond in a lawsuit it recently lost against the chemical-information company Leadscope in Columbus, Ohio. It had argued that the founders of Leadscope - former employees of the society — had used intellectual property belonging to the society. The ACS plans to appeal against the decision, but if it loses, it may owe that $\$ 36.5$ million plus interest. According to Glen Ruskin, director of the ACS office of public affairs, the possible outlay is "not having any impact on our financials at this point, nor did it figure in the actions we took on Tuesday [28 April]".

Of the 56 layoffs, 40 were in the publications division. Ten staff members at Chemical \& Engineering News and the entire reporting team at Environmental Science \& Technology

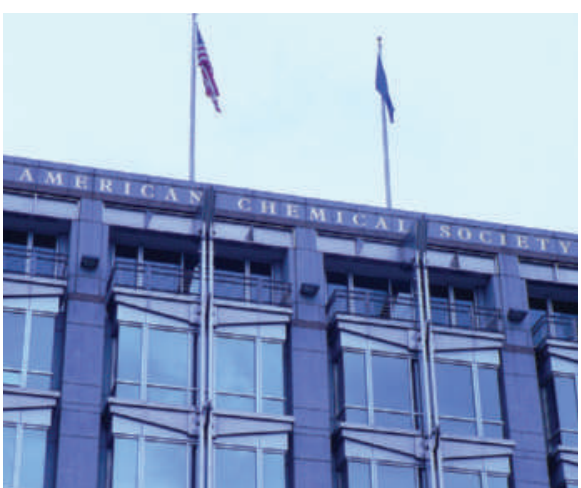

Hit by the downturn and the online revolution. access publishing aren't delighting in its financial woes. Peter Murray Rust of the University of Cambridge, UK, whose blog covers open-access chemical information, says that he wishes the society well. "I have not been a supporter of many of [its] policies," he says, "but I would say that we absolutely need national scientific societies."

Other societies are also seeing the value of their portfolios decline. "Our investments fared about as well as anyone's," says Mark Hernick, director of finance at the American Geophysical Union, also based in Washington DC. "Most investments lost 20 to $40 \%$ of their value last year alone, and we were in that category." He says that his society is not planning staffing reductions.

Richard Pike, chief executive of the London-based Royal Society of Chemistry, says, "Our reserves are hit, but we are in a somewhat better condition than some others - we had a good year ending in 2008". The UK society is actually adding staff, Pike says, mostly in its publications and membership divisions.

Ruskin says that he hopes ACS members won't notice any change in services provided by the society. "All the things that we provide to them are considered essential," he says. "How do we continue to provide that in a manner that is sustainable?" Emma Marris 